\title{
New currents in the research on esotericism and mysticism
}

https://doi.org/10.30674/scripta.91845

\section{EDITORIAL}

The present volume of Scripta Instituti Donneriani Aboensis is based on a symposium entitled 'Approaching Esotericism and Mysticism: Cultural Influences' and arranged by the Donner Institute together with the research project 'Seekers of the New: Esotericism and the Transformation of Religiosity in the Modernising Finland' at the University of Turku in June 2019.

The beautiful and hot summer days of early June were filled with enthusiastic discussions and debates on the concepts, contexts and contents within the study of esotericism and mysticism. The highlight of the conference was a trip to the Gallen-Kallela Museum in Espoo to see the exhibition 'Sielun silmä - Själens öga - Eye of the Soul' that presented the influence of esoteric and occult ideas on Finnish art, particularly at the end of the late nineteenth and early twentieth centuries. Some art works also illuminated the present interest in esotericism in contemporary art.

Both the project and the conference bespeak the current widespread and rapidly intensified research field concerning the study of modern western esotericism. Over ten years ago, in 2008, the Donner Institute arranged the first symposium in Finland concentrating on Western esotericism. Back then, there were lively discussions on the concept of esotericism as well as the scope of, at that time, a new and developing discipline. Subsequently a lot has happened, and the study of esotericism has evolved into a large, established, and well-known domain. Now it is possible to focus on a specific area within the study of esotericism. This conference focused on historical approaches.

Following the 2008 conference the project 'Seekers of the New' began slowly to build up, first as a loose network of Finnish scholars interested in the study of esotericism from various research fields (history, literary studies, cultural history, art history, study of religion) in order to connect and 
share mutual research interests. In 2017 the network, now forming into a more focused research group, received a three-year grant from the Kone Foundation, and since then ten researchers have worked together to study the influence of esoteric ideas and movements in Finnish cultural history from the late nineteenth century until the I930s. The project consists of several doctoral students writing their dissertations and senior scholars working with various research projects. The project has so far produced edited journal volumes, articles and museum exhibitions, and the researchers have presented papers and organised panels at various seminars and conferences, as well as organised courses at the University of Turku, and open lectures and events for the general public in different places in Finland. Last, but not least, in April 2020 a book on modern esotericism and occultism in Finland, led by Tiina Mahlamäki and Nina Kokkinen, was published by the academic publisher Vastapaino. Throughout the years we have encountered a wide, enthusiastic public response which has led to several radio programmes, newspaper interviews and articles - and, during the exceptional spring of 2020 , also to online events. Also, many students have shown their interest in the subject and are currently proceeding with their own studies in the context of the history of esotericism.

As the research concerning esotericism has extended over the past two decades into a very diverse field of study, from the study of religion into the fields of history, art, literature, music and popular culture studies, the approaches and theoretical perspectives have multiplied as well. The current enthusiasm in the research on esotericism resonates with the present culture, where popular literature, art and media have been active in presenting esoteric ideas, movements and individuals. This is visible in both, for example, fantasy literature and science fiction tv-series and movies, or in the interest in various forms of new-age spirituality. It is evident that there is a growing interest in esoteric, occult, and mystic themes not only within the multidisciplinary research field, but also among the general public.

At this conference, organised in June 2019, we wanted particularly to focus on cultural influences of esotericism and mysticism, and we encouraged participants to adopt a cultural-historical approach - an approach that accords also with the emphasis of the Donner Institute. The keynote lectures of the conference dealt with both the conceptual approaches in the research field as well as the history of esotericism, particularly in the nineteenth and twentieth centuries. 
This publication is based on the papers presented at the conference, and the articles approach the traditions of Western esotericism and mysticism from multidisciplinary perspectives of cultural history, the study of religion, art history, popular culture studies, and folkloristics. The aim of this volume is to analyse the diverse influences of esoteric ideas and practices and the various forms of mysticism in their cultural-historical surroundings. The articles focus on individuals, groups and networks, and benefit from various archival source materials, as well as published texts such as journals, novels, and different genres of popular culture.

The articles of this volume demonstrate the multidisciplinary essence and the vitality of the study of esotericism and mysticism. As one of the main foci of the 'Seekers of the New' research project is art in its different forms and shapes, the articles themselves also interpret the esoteric and mystic in many different art forms, as well as the influence of different esoteric thinkers - such as Emanuel Swedenborg, Aleister Crowley, G. I. Gurdjieff, and Rudolf Steiner - in historical and contemporary art and popular culture.

The content of this volume is divided into four sections. The first article, by Professor Olav Hammer from the University of Southern Denmark, concentrates on the main concepts of the conference theme - esotericism and mysticism - and how they are defined in different contexts. Hammer sees the concepts as being on the same continuum as that of religion.

The second section concentrates on individuals in the history of esotericism and mysticism. It begins with the article by the cultural historian, director of the research project 'Seekers of the New', Maarit Leskelä-Kärki. She reflects on the ethical challenges of studying individuals in esoteric research contexts as she analyses the archival material from the early i 900 s of the Finnish poet and writer Aarni Kouta. Other articles in this section open up the relations between the Finnish artist Sigurd Wettenhovi-Aspa and Swedish writer August Strindberg, written by Pekka Pitkälä, and the life narrative of G. I. Gurdjieff from the perspective of the history of wars and violence, written by Hippo Taatila.

In the third section, the focus turns to the esoteric and narratives in various novels. Tiina Mahlamäki and Tomas Mansikka present the Finnish author Laura Lindstedt, William Gray analyses the Turkish author Elif Shafak, and Carles Magrinyà discusses Cervantes' Don Quixote. The fourth and last section returns to the concepts within the study of esotericism and mysticism. The articles deal with the concepts of the vernacular (Kaarina Koski), magic (Tilman Hannemann), and the paranormal (Cristoffer 
Tidelius), that are essential within this research context. There is a need to look back, define and re-define the concepts used in the study of the esoteric and mystic, both in earlier as well as in contemporary research.

In the future, we would like to emphasise new approaches within the study of esotericism, and encourage diverse and multidisciplinary studies of ethics, politics, aesthetics, gender, and corporeality within esoteric currents, texts, ideas, and individuals. Also the methodological approaches within the study of esotericism should be developed further, and nor should we leave aside the conceptualisations and implementations of digital humanism, big data studies, and network analysis. The field of esotericism still remains a ground for new insights and new findings, both from the perspective of history and in our contemporary surroundings.

Turku Io June 2020

Maarit Leskelä-Kärki and Tiina Mablamäki 